\title{
エンジンオイルへの燃焼生成物混入メカニズムの解析*
}

\author{
村上靖宏*1, 相原久 元 $^{* 2}$, 国谷讓 治*2
}

\section{Analysis of Mechanism Intermixing Combustion Products in Engine Oil}

\author{
Yasuhiro MURAKAMI, Hisamoto AIHARA, and Jyôji KUNIYA
}

\begin{abstract}
It is widely known that NOx emissions from an engine play an important role in the formation of varnish and sludge in engine oil. Therefore, the authors measured the concentration of nitric and nitrous acid ions in the lubricating oil and analyzed the process through which NOx mixes into the lubricating oil. It was found that NOx mixes into the lubricating oil through oil film on the cylinder wall and through crankcase gas; and that the amount of NOx mixing into the the lubricating oil was proportional to the NOx concentration in the exhaust and crankcase gas. It was also found that a rapid increase in the concentration of nitrous acid ions when the engine temperature drops results in the condensation of water vapour contained in the crankcase gas.
\end{abstract}

Key Words : Lubrication, Internal Combustion Engine, Engine Oil, Varnish, Sludge

\section{1. まえがき}

往復動機関における潤滑の問題として燃焼に起因す るオイル少化，すなわち燃焼生成物の混入によるオイ ルの出化がある。燃焼生成物のうち特に水と $\mathrm{NO}_{x}$ は 反忘して硝酸，曹硝酸となってオイル中へ混入し，そ れ自体が腐食摩耗といった問題を引き起こすが,さら に $\mathrm{NO}_{x}$ は末燃然料と反応してワニス，スラッジのも とといわれるプリカーサ（液状酸化生成物）を生成す ることが知られている(1)〜(3). しかしながら，燃焼ガス 中の $\mathrm{NO}_{x}$ が，オイル中へエンジンのどこから，どの ような経過で，どのくらいの量混入するのかという点 については, 十分解明されていない(2).

ここでは,オイル中の硝酸, 垔硝酸イオン濃度を分 析することにより，燃焼ガス中の $\mathrm{NO}_{x}$ がオイル中へ 混入する経路とその混入量について調べた。さらに, エンジン油温, シリンダ壁温といったエンジン温度条 件が， $\mathrm{NO}_{x}$ の混入量におよ治寸影響を明らかにした ので報告する。

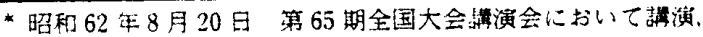
原椋受付昭和 62 年 2 月 2 日。

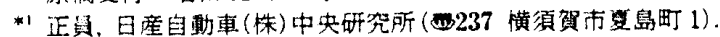

*2 日革自動車(株) 中央研究所.

\section{2. 実験装置および方法}

$2 \cdot 1$ 実験装置 本実験に用いたエンジンの諸元 を表 1 に，実験装置の概要を図 1 に示す。

排気組成は、 $\mathrm{CO}, \mathrm{CO}_{2}, \mathrm{HC}, \mathrm{NO}_{x}$ の震度を,クラン ク室内のガス組成は, それらに加えて $\mathrm{O}_{2}$ 濃度を非分 散形赤外線分析計 (NDIR), 水素炎イオン化検出器 (FID), 化学発光検出器 (CLD), 磁気式酸素計 (MOA) を用いて測定した。

クランク室ガスとシリンダヘッドカバー内ガスの組 成を分析し比較したが，両者に差がなかったため，ク ランク室ガスの組成のみを測定した.クランク室ガス は，流量が少ないため，一度バッグへ捕集した後に測

表 1 供試エンジン諸元

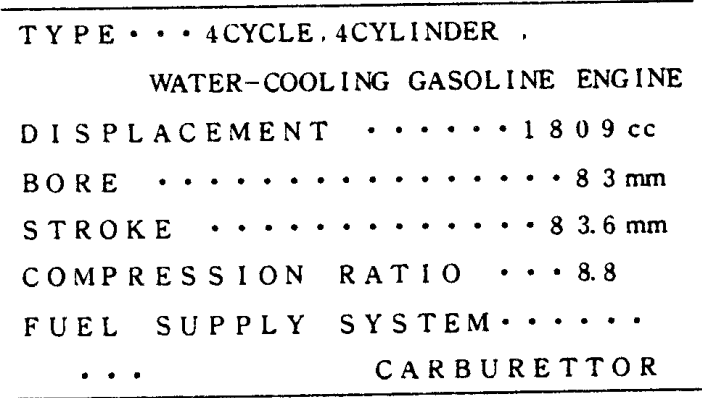




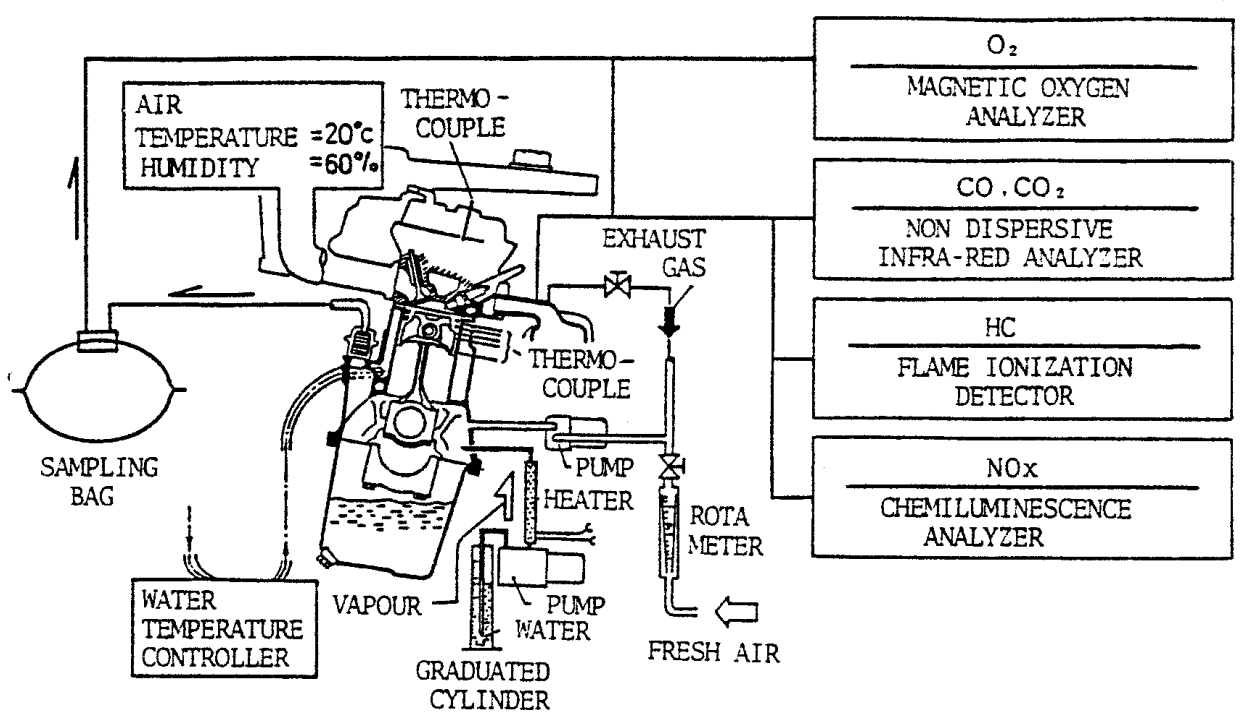

図 1 実験装置概要

定した。

エンジンの吸気条件は, 温度 $20^{\circ} \mathrm{C}$, 湿度 $60 \%$ にて 実験した。

オイルは, 7.5 W-30 SFを使用し充てん量は, $3 \mathrm{~L}$ 一定とした。また，実験ごとに新油による洗浄を2 回 行い,オイルおよびオイルフィルタを交換した。

\section{$2 \cdot 2$ 実験方法}

2・2・1 $\mathrm{NO}_{x}$ がオイルへ混入する経路 燃焼ガス 中の $\mathrm{NO}_{x}$ がオイル中へ混入する経路として，燃焼が スとオイルが接触する下記の経路（図2）が考えられ る.

(1) シリンダ壁の油膜およびピストンのリング溝の オイルを通して混入する経路

(2) クランク室・シリンダヘッドカバー内のガスか らオイルへ混入する経路

燃焼ガス中の $\mathrm{NO}_{x}$ は，燃焼〜排気行程中にシリン ダ壁の油膜に接触し，また燃焼ガスが燃焼室からクラ ンク室へ吹き报けるときにもピストンのリング溝のオ イルに接触する。(1)、これら両方の接触で混入する 経路を考える。

ブローバイとしてクランク室, シリンダヘッドカバ 一内に流入した $\mathrm{NO}_{x}$ は，オイルパン, シリンダヘッ ドカバー内のオイルと接触する。 (2)は、ここで混入す る経路を考える。

$2 \cdot 2 \cdot 2$ 混入量の測定方法燃焼ガス中の $\mathrm{NO}_{x}$ は，オレフィンなどと反応してエステルなどを生成す ることが知られている(4). しかし，10hぐらいの運転 では赤外分光分析計による分析で，オイル中にエステ ルなどの有㙨の等素酸化物は検出されなかった。

そこで，本報ではオイル中の硝酸，严硝酸を水で抽

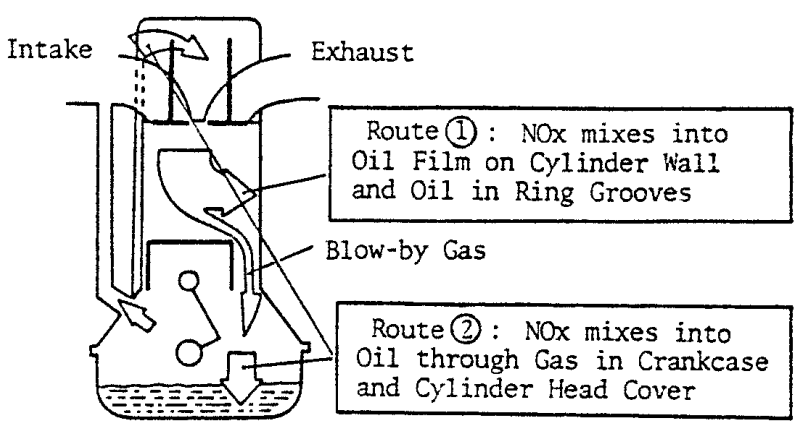

図 $2 \mathrm{NO}_{x}$ がオイルへ混入する経路

出し, 硝酸イオン $\left(\mathrm{NO}_{3}{ }^{-}\right)$, 西硝酸イオン $\left(\mathrm{NO}_{2}^{-}\right)$をイ オンクロマトグラフィで分析した.

各 $\mathrm{NO}_{x}$ 混入経路からの混入量は, 次のようにして 調べた. (1)の経路ではオイルに燃焼ガスが直接接触し， (2)の経路では，クランク室がスがオイルへ接触する。 そこで, 排気中 $\mathrm{NO}_{x}$ 濃度とクランク室ガスの $\mathrm{NO}_{x}$ 濃 度を別々に変化させ，一定時間運転した後オイルパン より採取したオイル中の硝酸，垔硝酸イオン漕度の変 化を調べた。

排気中 $\mathrm{NO}_{x}$ 濃度は，空燃比あるいは負荷の調整に て変化させた。

クランク室およびシリンダヘッドカバー内ガスの $\mathrm{NO}_{x}$ 濃度は,クランク室に, 排気の一部を導入するこ とで変化させた，その際，排気のみを導入する場合と 排気を空気で希釈して導入する場合を比較することに より, 排気遱入時のクランク室ガスの流量の変化の影 響についても検討を加えた。

さらに, エンジン油温とシリンダ壁の温度が、オイ ルへの $\mathrm{NO}_{x}$ 混入量へおよぼす影響について調へた。 
エンジン油温, シリンダ壁温は, エンジン冷却水温度 および車载形水冷式の小形油冷却器により調整した。 シリンダ壁の温度は，\#1気简で測定し，ピストンが上 死点と下死点の中間にあるときの圧縮りングの位膡の 壁温度を代表温度とした.

\section{3. 实験結果およひ考察}

\section{$3 \cdot 1 \quad \mathrm{NO}_{x}$ の混入経路と湿入量}

$3 \cdot 1 \cdot 1$ 排気中の $\mathrm{NO}_{x}$ 湿度との関係空燃比抢 よび負荷により排気中 $\mathrm{NO}_{x}$ 灌度を変えたときのオイ ル中の硝酸，重硝酸イオン濃度の変化を図 $3 ， 4$ に示 す. 空燃比を変えたとき，排気中 $\mathrm{NO}_{x}$ 濃度は空燃比 16 付近て最高となるが，オイル中の硝酸，西硝酸イオ ン濃度もそれにともなって空燃比 16 付近で最高とな っている.

一方，負荷を変えたとき，負荷の增大とともに排気 中の $\mathrm{NO}_{x}$ 瀑度も增えるが，オイル中の硝酸，西硝酸 イオン濃度も增加している。

図 5 に図 $3 ， 4$ の結果を排気中の $\mathrm{NO}_{x}$ 瀆度で整理 し直したものを示す.オイル中の硝酸，垔硝酸イオン とも, 排気中 $\mathrm{NO}_{x}$ 瀑度の増加に対して直線的に增加 している.また，业硝酸イオンの摆度は，硝酸イオン濃 度に比べて低い.

$3 \cdot 1 \cdot 2$ クランク室内 $\mathrm{NO}_{x}$ 濃度との成係排気 を晸入して,クランク室内の $\mathrm{NO}_{x}$ 濃度を変えたとき のオイル中の硝酸，西硝酸イオン謴度の変化を図 6 に

ENG. SPEED: $1500 \mathrm{rpm}$ TORQUE : $49 \mathrm{~N} \cdot \mathrm{m}$ IGN.TIMING:MBT

OIL.CYLINDER WALL TEMP. : $80^{\circ} \mathrm{C}$ TEST HOURS $: 3 \mathrm{~h}$

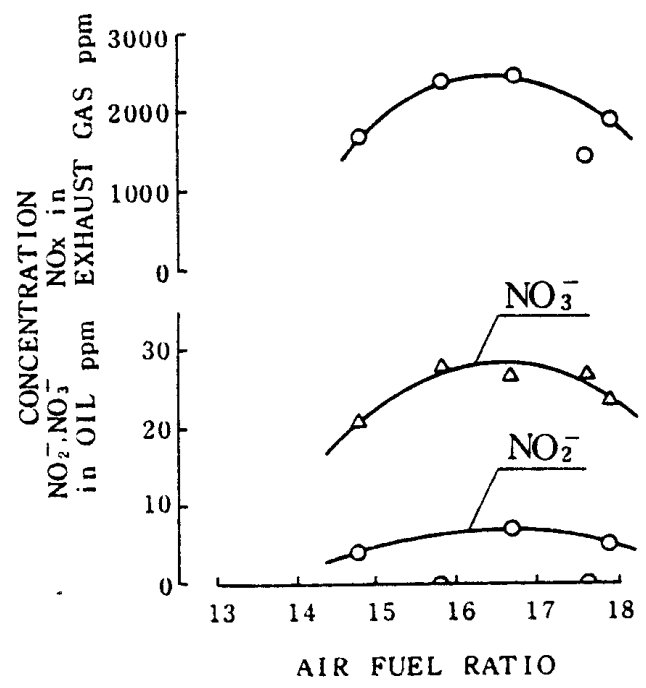

図 3 空燃比とオイル中硝酸, 亚硝酸イオン瀑度
示す.

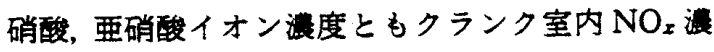
度の増加に対して直線的に増加している。また，クラ ンク室に導入されるガスの流量は, $\mathrm{NO}_{x}$ 灌度が同じ 場合，空気で希釈するほうが多くなるが，このときオ イル中の硝酸, 要硝酸イオン灌度は空気の希釈の有無 による差は少なく, $\mathrm{NO}_{x}$ 灌度に対して同じ値を示し ている.これは, $\mathrm{NO}, \mathrm{NO}_{2}$ を含んだ $\mathrm{NO}_{x}$ の水への吸 収速度が $\mathrm{NO}_{x}$ を含んだガスの流量によらず， $\mathrm{NO}_{x}$ の 湿度のみに依存することを報告したGarciaの結 果 $^{(5)}$ と一致する。

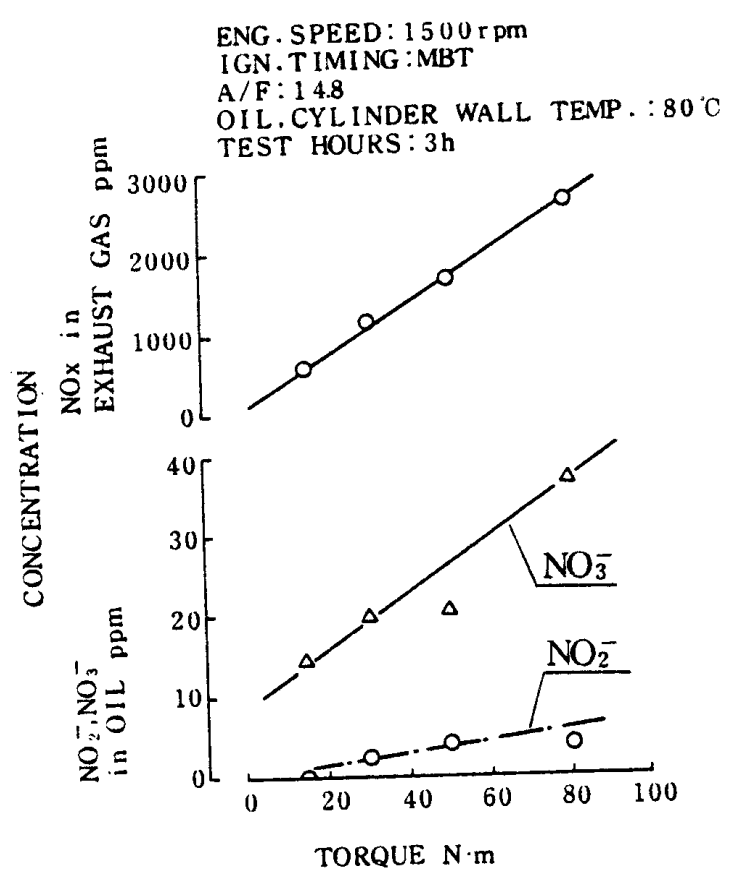

困 4 負荷とオイル中硝酸, 要硝酸イオン濃度

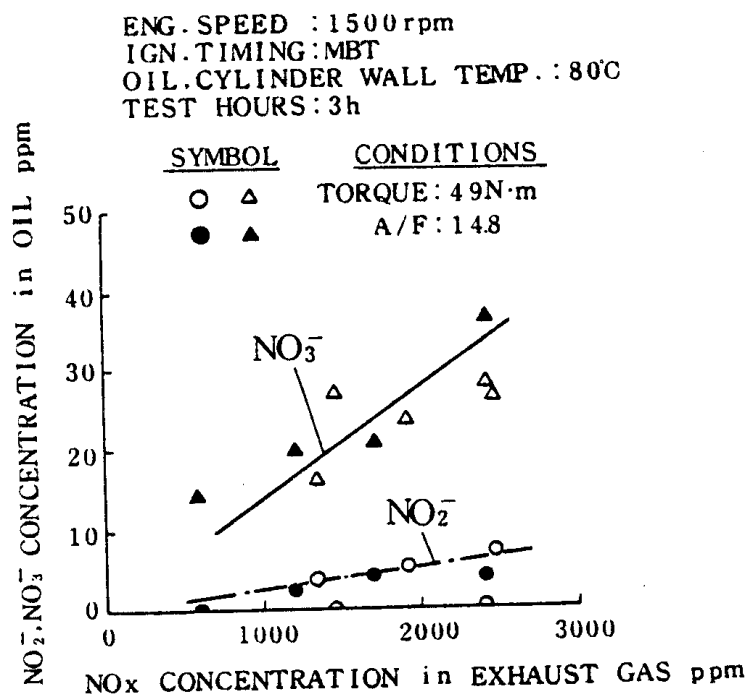

図 5 排気中の $\mathrm{NO}_{x}$ 濃度との関保 
$3 \cdot 1 \cdot 3$ 燃焼ガス中の $\mathrm{NO}_{x}$ がオイルへ混入する経 路上混入量 排気中 $\mathrm{NO}_{x}$ 浱度於よびクランク室内 $\mathrm{NO}_{x}$ 浱度が増加すると, オイル中の硝酸, 重硝酸イオ ン濃度は, ともに直線的に増加することがわかうた。 以上の結果をもとに図 2 に示す混入経路からの要硝 酸，硝酸イオンの混入量について考察した。

図 6 において,クランク室内の $\mathrm{NO}_{x}$ 灌度が 0 ppm のときの垔硝酸イオン濃度を外挿によりもとめるとほ ぽ0 ppm となる. したがって,オイル中で重硝酸イオ ンとなる $\mathrm{NO}_{x}$ は, $2 \cdot 2 \cdot 1$ 項の経路(2)より混入すると 考えられる. 図 5 において, 排気中の $\mathrm{NO}_{x}$ 灌度の増加 に対して亚硝酸イオン蕽度も増加するが,これは燃焼 により発生した $\mathrm{NO}_{x}$ 濃度の増加によりクランク室・ シリンダヘッドカバー内の $\mathrm{NO}_{x}$ 浱度も増加するため である。

一方, 硝酸イオン濃度は, クランク室内の $\mathrm{NO}_{x}$ 濃 度が $0 \mathrm{ppm}$ であっても図 6 に示すように $0 \mathrm{ppm}$ とな らず約 $14 \mathrm{ppm}$ となる. したがって, オイル中で硝酸 イオンとなる $\mathrm{NO}_{x}$ は, $2 \cdot 2 \cdot 1$ 項の経路(1)からも混入 し, その量は図 6 のエンジン運転条件, $1500 \mathrm{rpm}$,

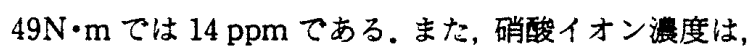
クランク室内の $\mathrm{NO}_{x}$ 摆度の增加に対しても, 西硝酸 イオン濃度の増加に近い増加率で増えており,オイル 中で硝酸イオンとなる $\mathrm{NO}_{x}$ は, $2 \cdot 2 \cdot 1$ 項の経路(2)か らも湿入すると考えられる。

各経路(1)，(2)から混入して硝酸イオンとなる $\mathrm{NO}_{x}$ の各量は次のように考えられる。

$1500 \mathrm{rpm}, 49 \mathrm{~N} \cdot \mathrm{m}$ では, クランク室内の $\mathrm{NO}_{x}$ 濃度

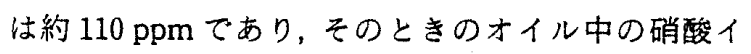

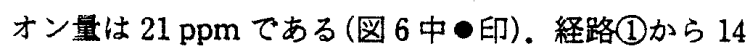
ppmが混入するので経路(2)からの混入量は $7(=21$ -14)ppmである.

したがって，オイル中で硝酸イオンとなる $\mathrm{NO}_{x}$ は 主として 2・2・1項の経路(1)より混入すると考えられ る.

\section{$3 \cdot 2$ エンジンの温度条件が NO の $_{x}$ 湿入量に与え る影響}

$3 \cdot 2 \cdot 1$ 油温, 壁温と $\mathrm{NO}_{x}$ 混入量 エンジン油温 とシリンダ壁温を同時に変化させたときのオイル中硝 酸, 覀硝酸イオン濃度を図 7 に, ガソリンおよび水分 濃度を図 8 に示す. 硝酸イオン濃度は, エンジン油温 とシリンダ壁温の変化に対してほぼ一定だが, 覀硝酸 イオン濃度は, 温度の低下とともに $40^{\circ} \mathrm{C}$ 付近で急激に 增加している.オイル中のガソリンおよび承分濃度も， 温度の低下とともに增加するが, 特に水分は, $40^{\circ} \mathrm{C}$ 付 近から急增し, 垔硝酸イオン濃度の增加傾向と一致し
ている.これは、エンジン油温，シリンダ壁温の低下， すなわちエンジン全体の温度低下により，まずクラン ク室ガス中の水分が凝縮し，そこへ $\mathrm{NO}_{x}$ が吸収され， 水とともにオイルへ混入するためと考えられる.

そこでシリンダへッドカバー内側の表面温度を測定 し,クランク室ガス成分より水の点点を計算したとこ

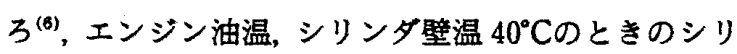
ンダヘッドカバー内側表面温度は, $29^{\circ} \mathrm{C}$, クランク室 ガス中水分の露点は， $31.5^{\circ} \mathrm{Cであったまたこのと}$ き,シリンダへッドカバー内側表面に付着したオイル は，白濁していた．したがって図 7 におけるエンジン 油温，シリンダ壁温の低下による亚硝酸イオン湜度の 急增は，クランク室ガス中水分の凝縮が主因と考えら れる.

$3 \cdot 2 \cdot 2$ 水分の频縮と $\mathrm{NO}_{x}$ 混入量 シリンダへ ッドカバー内側表面で水分凝縮が発生しないエンジン 温度 (エンジン油温, シリンダ壁温 $60^{\circ} \mathrm{C}$ ) において, ク ランク室に水蒸気を尃入したときのオイル中の覀硝酸

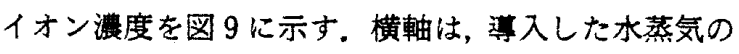
量で，図1に示したメスシリンダにて水の状態で測っ
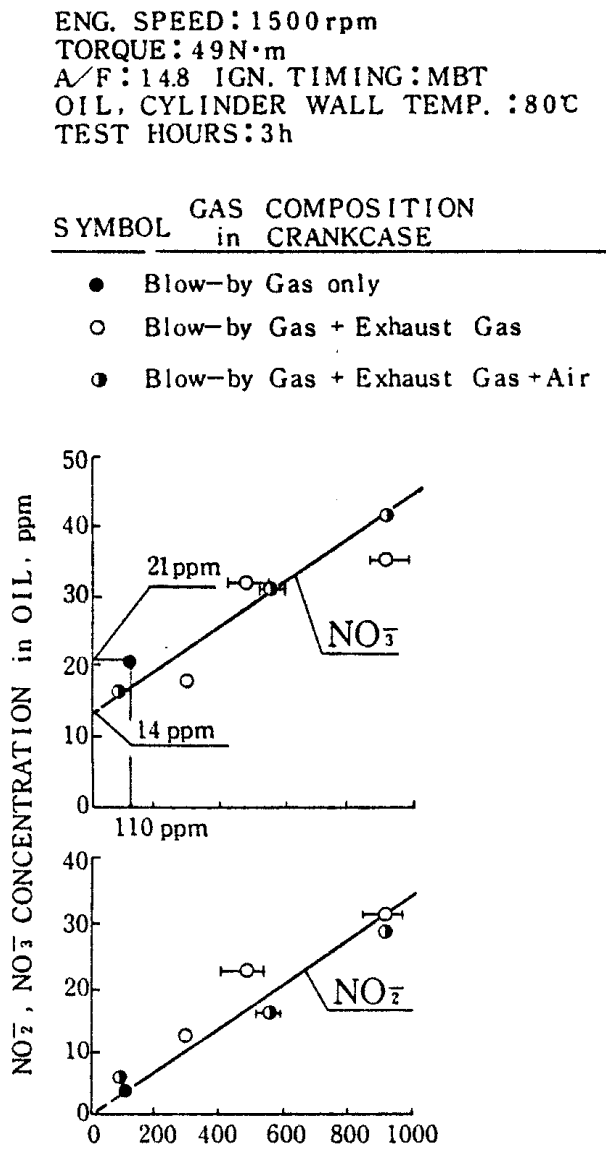

NOx CONCENTRATION in CRANKCASE ppm 図 6 クランク室内の $\mathrm{NO}_{x}$ 湦度との成倸 
た量てある. 水蒸気を導入した場合, シリンダヘッド カバー内側表面に付着したオイルは白罣していた。

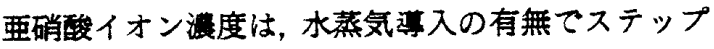
状に増加している。これは，次のように考えられる。

水蒸気道入によりエンジン油温, シリンタ壁温 $60^{\circ} \mathrm{C}$

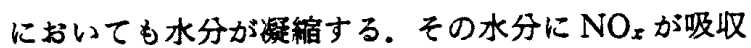
されオイルへ混入するためオイル中の垔硝酸イオンが 増加する. しかし, 水蒸気量を増加してもクランク室 内の $\mathrm{NO}_{x}$ 濃度が変わらないため, 水に混入てきる $\mathrm{NO}_{x}$ の量が律速となり，オイル中の亜硝酸イオン灌 度は増加せず一定になったと考える。

3・2・3 クランク室がス温度が $\mathrm{NO}_{x}$ 混入に与える 影響エエンジン油温, シリンダ壁温が $60^{\circ} \mathrm{C}$ とき, 水蒸気算入によりシリンダヘッドカバー内で水分を凝 縮させた場合, 西硝酸イオン湿度は, 運転時間 $3 \mathrm{~h} て$ 26ppmであった(図 9).これに対して，クランク室ガ ス中の水分が凝縮する $40^{\circ} \mathrm{C}$ ときは, 同じ運転時間て $50 \mathrm{ppm}$ である。これらの実験を行ったときのクラン ク室内 $\mathrm{NO}_{x}$ 濃度は，それぞれ $200,230 \mathrm{ppm}$ と差が少 ない。それにもかかわらず，垔硝酸イオン浱度が約 2 倍も異なっており，水分の凝縮以外の要因が考えられ る. 現在さらに検討を進めている。

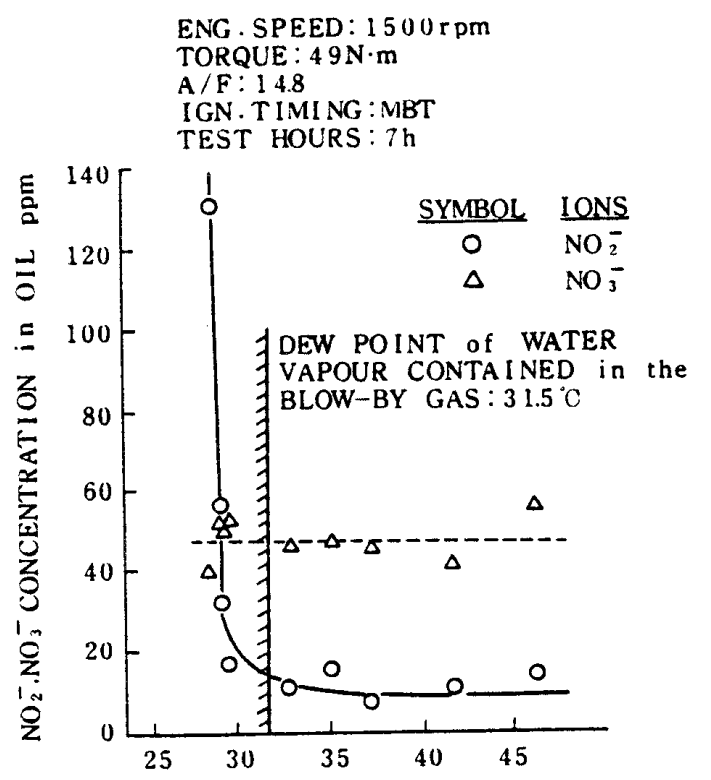

CYLINDER HEAD COVER INNER SURFACE TEMPERATURE ${ }^{\circ} \mathrm{C}$

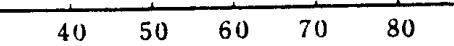

OIL.CYLINDER WALL TEMPERATURE C

図 7 エンジン温度の影響（硝酸，垔硝酸イオン瀑度）

\section{4. ま と め}

スラッジ生成の要因と考えられている燃佬ガス中の NOxのオイルへの混入経路と量を調べた結果以下の 知見を得た。

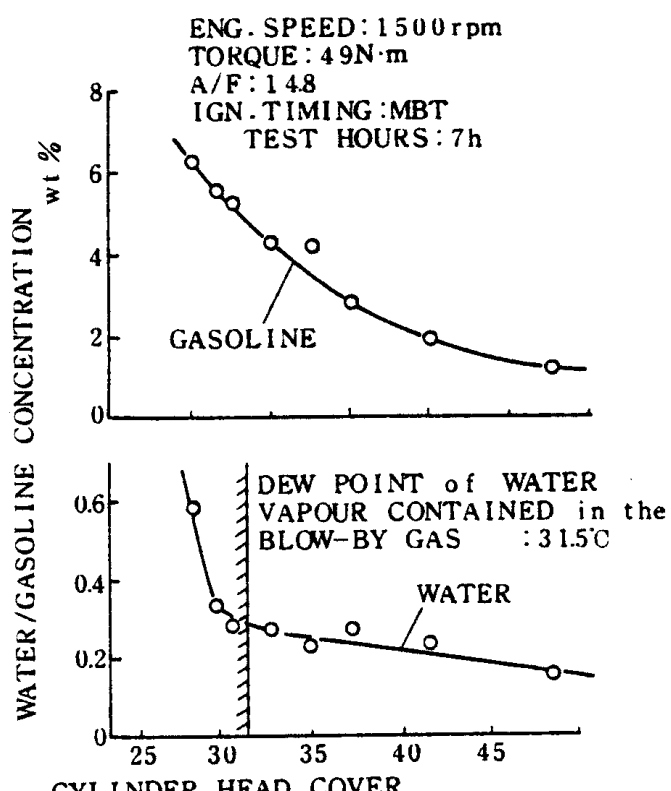

CYLINDER HEAD COVER

INNER SURFACE TEMPERATURE 'C

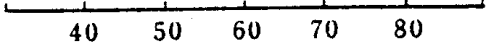

OIL.CYLINDER WALL TEMPERATURE 'C

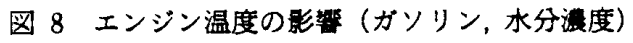

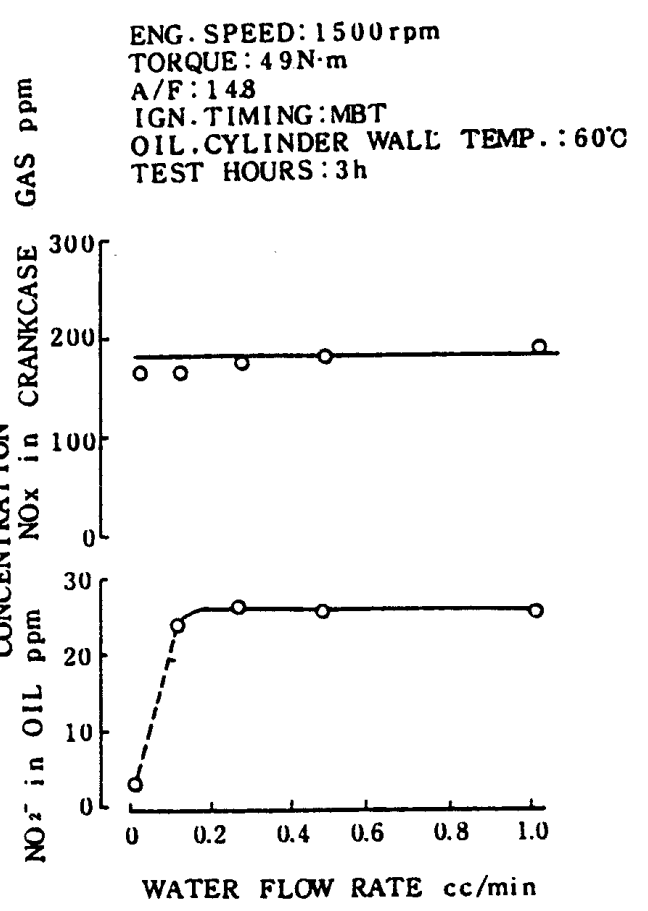

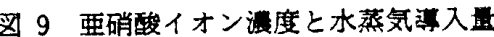


（1）混入経路 オイルへ混入する燃燒ガス中の $\mathrm{NO}_{x}$ のうち

・オイル中で硝酸イオンとなる $\mathrm{NO}_{x}$ は, 主にシリン ダ壁の油膜およびピストンのリング㴖のオイルを通し て混入する。

・オイル中で垔硝酸イオンとなる $\mathrm{NO}_{x}$ は, クランク 室およびシリンダヘッドカバー内のガスょり混入す る.

（2）混入量 オイルへの $\mathrm{NO}_{x}$ 混入量は, 排気 およびクランク室ガス中の $\mathrm{NO}_{x}$ 湦度に比例して増加 する.

(3) エンジン温度条件

・オイル中の悪硝酸イオンの量は, エンジン温度が 低下すると急激に増加する。

・このとき, シリンダヘッドカバー内側の表面温度 とクランク室ガス中水分の露点とは，ほほ一致する。
・上記より低温時のオイル中の西硝酸イオン灌度の 急增には, クランク室ガス中水分の疑縮が強く影䇾し ていると考えられる。

\section{文献}

(1) Vineyard, B. D. and Coran, A. Y., Am. Soc. Preprint, Div. Petrol. Chem., 14, A-35 (1965).

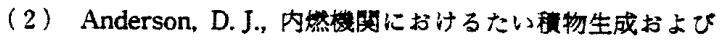
摩耗一最近の進步-, 石油学会誌, 12-4 (昭 44).

(3) Dimitroff, E., Moffilt, J.V. and Quillian, R.D., JR.. Why, What, and How: Engine Varnish, Trans. ASME, J. Lubr. Technol. (1969), 406.

（4）日本化学会編，新化学実駼詿 14 ：有機化合物の合成と 反応 III, (昭 51)，1286, 丸蕃出版.

(5) Garcia, L.H., Proceedings of Second International Lime/Limestone Wet-Scrubbing Symposium. II (1972), EPA, USA

（6）古浜・加藤，自動車用ガソリンエンジンのクランク室ガ スの成分，自動車技衝，24-4（昭 45).

討論

[象間〕副岛 光 洋〔九州大学工学部]

エンジン油ワニス，スラッジの生成機桠解明の手挂 りを与える贵重な研究結果を示されたことに敬意を表 す.そこで,

（1）図 8 に示されているガソリンの希釈がワニ ス，スラッジ生成の主因であるとすれば，その量の工 ンジン負荷, 回転数, 水温などによる変化を詳しく知 る必要がある。そのあたり，実験データがあれば示し ていただきたい.

（2） $\mathrm{NO}_{x}$ の混入経路を硝酸と亜硝酸に分けて調 べられているが, 結局 $\mathrm{NO}_{x}$ の各酸への反応凝縮の条 件をどのように考えるべきか，また硝酸，悪硝酸のど ちらがワニス，スラッジ生成に強くかかわるかについ て，教えていただきたい。

（回答）（1）図4の実験を行ったときのオイル 中ガソリン濃度を示す，トルクの増大に対して増える 傾向にある.また $4000 \mathrm{rpm}$ 全負荷(空燃比 14.8 , 油水 温 $80^{\circ} \mathrm{C}$ )では $2.2 \%$ になった。これらは、シリンダ壁の 油膜へ混入するガソリンが Henry の法則に従い同一 空燃比の場合, 温度が一定ならばシリンダ内厈力が高 いほどオイルへ溶解するガソリン襄度が高くな る(付1)ことと矛盾しない, 著者らは, 回転数扔よび氷 温のみを変化させたデータを有していないのでこれら の影蠁について論じることはできない.しかしながら， エンジンの温度条件についてガソリン希釈を考える場 合, その溶解, 放出過程からシリンダ壁温, 油温が重
要な因子であると考えている.

（2）著者らは燃焼ガス中の $\mathrm{NO}_{x}$ がオイルへ混入 する条件によって，なぜ硝酸イオンまたは亚硝酸イオ ンになるかを十分説明できる资料を持っていない。

ワニス，スラッジの生成については次のように考え ている.

エンジン温度の低下にともないオイル中で西硝酸イ オンとなる燃焼ガス中 $\mathrm{NO}_{x}$ が急增した。 また，硝酸， 西硝酸イオンが検出された使用斉みオイルでモータリ ングを行ったところ,オイル中の硝酸イオン湿度には 変化がないのに対し，覀硝酸イオン濃度は減少した。 したがって, $\mathrm{NO}_{x}$ がその生成に重要な役割を果たし ていると言われる低温スラッジ生成については, 亜硝 酸イオンとなる $\mathrm{NO}_{x}$ が強くかかわっていると考え る、ワニス，高温スラッジについては，熱の作用があ り，オイル自体の酸化もあるので，どちらとも言えな w.

(算問) 許婓 明

〔トヨタ自動車侏東富士研究所〕

エンジンオイルへの硝酸, 亜硝酸の混入過程に関す る精剩な実験に敬意を表す。下記 3 点についてお教え 願いたい.

（1）オイル中で硝酸イオンとなる $\mathrm{NO}_{x}$ は主とし てシリンダ周辺から，垔硝酸イオンとなる $\mathrm{NO}_{x}$ はク ランク室およびへッドカバーから混入するとの結論で あるが,どのようなメカニズムでそのようになるの 


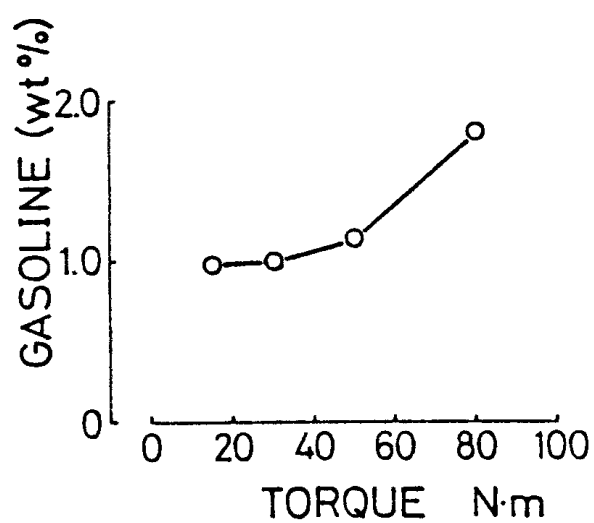

付図 1 オイル中のガソリン嬢度

か.

（2）質問者のピストン摩擦力計測の経験では，膨 張及び排気行程で，燃焼ガスに暴露されるシリンダ表 面には油膜が残っていないように思われる。このよう な場合でも，硝酸イオンとなる $\mathrm{NO}_{x}$ がシリンダ周辺 からオイルに混入することが考えられるか。その場合 のメカニスムについてお教え願いたい。

（3）ブローバイガスには燃焼過程の成分, 未燃成 分が含まれ，排気ガスおよびこれに空気混入した場合 と組成が異なる。この傾向が図 6 に現れていると思う が,どのような組成の違いが影䇾しているのかについ て、見解をお聞せいただきたい。

〔回答〕（1）オイル中に溶け込んだ然焼ガス中 の $\mathrm{NO}_{x}$ が，その混入経路の違いから，なぜ硝酸イオ ンまたは亜硝酸イオンと異なった酸イオンとして検出 されるかについては不明てある. 混入する箶所の温度, 圧力条件の違いが原因の一つであろうと予想してい る.

（2）著者らの知るところ，McGeehanら(付 2)が， シリンダ表面の油膜が上死点, 下死点付近で途切れ， リングとライナが直接触れ合うところがでてくること を報告しているが，同時にそれ以外のところでは油膜 の存在を行程にかかわらず示している．また燃焼ガス はピストンのリング瑇中のオイルにも接触する。した がってシリンダ周辺において燃焼ガス中の $\mathrm{NO}_{x}$ がオ イルへ混入する機会は十分に存在すると考える。

(3) ご指摘のように,ブローバイとしてクランク 室に流入したガスと排気ガスおよび空気混入したガス とはHCの組成が異なる。

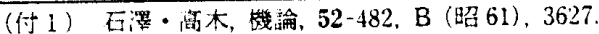

(付 2) McGeehan, A. D., A Litterature Review of the Effects of Piston and Ring Friction and Lubricating Oil Viscosity on Fuel Economy, SAE Paper 78067.3 (1978)

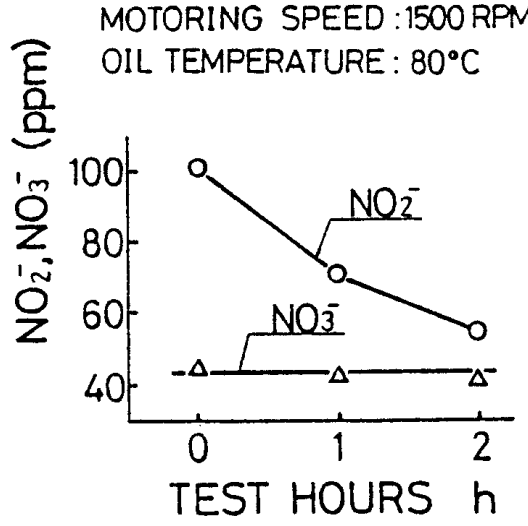

付図 2 モータリングによる硝酸，重硝酸イオン瀑度 の変化

ご質問の内容は, 図 6 のオイル中の硝酸イオン濃度 を示したグラフで,ブローバイガスのみのときの硝酸 イオン量 (図中○印) が, 排気ガスおよび空気混入した ガスをクランク室へ萁入したときと比べて高い值を示 すことへの HC 組成の影锝についてと思われる。

これは、図 6 に示した実験を行うにあたりエンジン の運転条件を同一としたが，問題の実験点では，排気 中の $\mathrm{NO}_{x}$ 濃度が他の点に比べて高くなってしまい, 図 5 に示す関係から硝酸イオン漢度に影響がでてしま つた。

著者らの見解として，HCの組成の違いが $\mathrm{NO}_{x}$ の オイルへの混入におよはす影響は, 図6においてはな いと考えている.

[䓄問)石川栄(日本石油划)

エンジンオイルの劣化機構を解明する貫重な研究成 果に敬意を表す。

本研究では, $\mathrm{NO}_{x}$ のエンジンオイルへの湿入経路 を解明され， $\mathrm{NO}_{x}$ の濃度の增加およびエンジン温度 の低下によって $\mathrm{NO}_{z}$ のエンジンオイル中への混入が 増加することを明確化されておられるが, エンジンが 実際に使用されるような条件（例えばモード運転）て 運転された場合，オイル中の $\mathrm{NO}_{2}{ }^{-}, \mathrm{NO}_{3}{ }^{-}$がどのよう な挙動を示すか知見があったらご教示下さい.

また，エンジンオイル中へ混入する $\mathrm{NO}_{x}$ の量を減 らす方法としてブローバイガスのベンチレーションシ ステムが重要な鍵を握ると思われるがこの点に関する お考えをお聞かせいただきたい。

(回答) ワニス，スラッジの生成で問題となる発 進・停止形のモード運転を行った結果，オイル中の垔 硝酸，硝酸イオンとも図 5 に示す関係で運転時の排気 $\mathrm{NO}_{x}$ 湛度に相当する量が混入することがわかった。 た，環境温度を变えて同じモード運転を行ったところ， 
亜硝酸イオン量は環境温度の影響を受け，温度が低い ほど増える傾向が見られた。

ご指摘のとおりで, 著者らもエンジンオイル中へ混 入する $\mathrm{NO}_{x}$ 量の低隇に果たすブローバイベンチレー ションシステムの役割は重要と考えている，本論文の 結果によればブローバイベンチレーションシステムの 改良により低隇できるオイルへの $\mathrm{NO}_{x}$ 混入量は, ク ランク室およびロッカカバー内より湜入する量であ
り，その量はクランク室ガス中 $\mathrm{NO}_{x}$ 港度に比例し， クランク室ガス中水分の凝縮とともに急增する。

したがってブローバイベンチレーションシステムを 検討するうえて,クランク室ガス中 $\mathrm{NO}_{x}$ 濃度を低減 すること，またクランク室およびロッカカバー内の温 度をガス中水分の路点以下に下げないことを考虑する 必要があると考える。 